\title{
On Modern Technology Diffusion and Ancient Science in Africa
}

\author{
Stephen O. Ekolu \\ Department of Civil Engineering Science, University of Johannesburg, \\ Auckland Park 2006, South Africa \\ sekolu@uj.ac.za, sekolu@gmail.com
}

\begin{abstract}
This paper discusses the disparities leading to technology transfer in developing countries and attempts to explain this process using the diffusion theory. Scientific studies have shown that cognitive abilities have no role in the present under-development of SubSaharan Africa (SSA). These issues are discussed in consideration of the universalist nature of the Science, Engineering and Technology disciplines. It is shown from literature that ancient Africa was not devoid of great science. The necessity to majorly grow modern endogenic science in SSA is emphasized as a basis for an optimistic outlook towards posterity.
\end{abstract}

Keywords: Indigenization, diffusion theory, universalism, domestication, cognitive intelligence, ancient science

\section{Introduction}

Education and the economy appear to be the two particularly most powerful domains and engines for development. Presently, the curricula and language of instruction among African higher education institutions (HEIs) are predominantly oriented or drawn from international sources including the books, concepts and principles studied in Science, Engineering and Technology (SE\&T). The reason for this scenario is the current lack of SE\&T skills and the highly skilled human resource needed. This interaction between developing and developed countries is explained by the diffusion theory [1]. Scientifically, diffusion mechanism is the natural flow of an agent from a point of high concentration to that of lower concentration. This process continues until equilibrium is attained. Reverse flow cannot result unless there is an endogenic input to elevate the lower end to a concentration level that is greater than that of supply side. When applied to the African context, the theory may partially explain the observed limited domestic innovation and reliance on international sources for technologies. At the same time, technology transfer through, for example, building of mega-engineering projects for water and energy, require the acquisition of loans from technology donors. So the capital accumulation and wealth benefits from the technology supply are eroded through re-payment of loans with interest while returns per capita are depleted by high population growth in developing countries. In this paper, domestication of technologies from international sources, is discussed while considering universalism of SE\&T fields. Considering that ancient science existed in Africa, future development anchors heavily on progress in endogenic science.

ACRID 2017, June 20-21, Victoria Falls, Zimbabwe

Copyright (C) 2017

DOI 10.4108/eai.20-6-2017.2270658 


\section{Universalism of Natural Sciences}

SE\&T concepts are considered to be fundamental and applied principles that are universal in nature and drawn from natural laws. They hold no boundaries other than scientifically established limits of application. These principles cannot be altered by human opinions or interpretations, and are demonstrable through repeatability and reproducibility. Due to the reproducible nature of universal principles, they can be reliably employed without the fear of going wrong, provided they are applied within their established bounds of validity. For these reasons, universal scientific principles serve all humanity alike. They are blind to opinions, are faithful servants of society to its core and are drivers of the common good. These universal principles consist of methods and procedures usually established through sound scientific research upon specific natural phenomena or behavior. They can be expressed empirically through trends or mathematical processes or equations. This knowledge forms the basis for engineering technologies and related end products for end user consumption [2].

\section{Cognitive Abilities}

Compared to all other world regions of East Asia and Pacific, Europe and Central Asia, Latin America and Caribbean, Middle East and North Africa, South Asia, SubSaharan Africa (SSA) has the worst indicators of development with 42.7\% (2012) of the population living below $\$ 1.90$ per day. The region has the shortest life expectancy of 51 years in 2009 which has improved to 58 years in 2013. SSA's population is 973.4 million (2014) growing at $2.74 \%$ annually $[3,4]$.

Cognitive abilities of black Africans have been questioned, sometimes through unsubstantiated eugenic theories and scientific methods. A case in point are the scientific IQ studies conducted by researchers [5-8] who used their findings to support claims that the IQ of Africans is low. Later, scientists have found such claims to have been based on flawed science. Wicherts et al. [9] examined, perhaps nearly all the then available IQ studies conducted on Africans from 1988 to 2006, and found about 2500 papers. The data were subjected to scientific methods of sample selection criteria and then analysed. They found that the average IQ had no indication to general intelligence among Africans. Furthermore, environmental factors that are known to improve IQ such as good health, better nutrition, opportunities to education etc. lack among most of Africa's young population [9].

\section{Ancient Scientific Discoveries and Engineering Feats in Africa}

Archeologists have reported various sources of evidence showing past existence of scientific knowledge in ancient Africa [10,11]. Prior to the Egyptian civilization, there were amazing scientific inventions in ancient Africa, ranging from mathematical sciences and astronomy, through to materials engineering and medicine. Table 1 gives a summary of these ancient scientific advances. 
At the shores of Lake Victoria in Tanzania, Uganda and Rwanda was discovered a steel smelter 1500-2000 years old, used for production of carbon steel through crystal growth i.e. semi-conductor technology far different from the iron smelting technology invented later in Europe. The temperature of African furnace was 200 to $400^{\circ} \mathrm{C}$ higher than that of Roman furnaces of $2^{\text {nd }}$ century which only reached up to $1600^{\circ} \mathrm{C}$. The Cushites of Kenya, located at a place named Namoratunga meaning the "Stone people", created an ancient African observatory, consisting of a stone calendar which was based on rising of certain stars and constellations. The Dogon of Mali surprised the modern world of astronomy, when it was discovered that they possessed precise knowledge of an invisible Sirius $B$ star, which orbits Sirius $A$ elliptically every 50 years. The Dogon people, who have no telescopes, plotted the orbits of this star from hundreds of years ago to year 1990 . Western astronomers only confirmed these claims of Dogon astronomy in the $20^{\text {th }}$ century. The Dogon people are located about 200 miles from the ancient University of Timbuktu. Ancient Egyptians invented the modern calendar, dividing the year into 12 parts and 3651/4 days. The earliest recorded use of mathematics was among the Egyptians, consisting of complete algebra of additions, subtractions, divisions, multiplications including calculation of distances, areas and volumes of various shapes. They gave a circle its $360^{\circ}$ angle and $\pi$ its value of 3.16. But recent discoveries show that the Ishongo of the Democratic Republic of Congo (DRC), had developed a lunar calendar system much earlier about 8000 years ago, while Yoruba of Nigeria have maintained continuity of base 20 numerical counting systems throughout their civilization, complete with addition, subtraction and multiplication.

Egyptian pyramids present an astounding marvel of any engineering project in human history. There are more than 80 pyramids but the largest covers 13 acres and is made of 2.25 million blocks of stone. The Giza pyramid, declared one of the seven wonders of the world, is estimated to have taken 20 years to build using two-ton blocks of stone that had to be transported up to $174 \mathrm{~m}$ height. A large stone city complex is found 17 miles south of Zimbabwe's city of Nyanda. This $12^{\text {th }}$ century African empire, known as Monomotapa lasted for 300 years. Some of its granite walls were $250 \mathrm{~m}$ long and built of a 15000 ton granite wall. The great stone complex built by the Shona people housed the kings family, court officials, servants and traders.

West and Central Africa was an interlocked network of trade routes, from the Mediterranean to the Gulf of Guinea and from the West Coast to Lake Chad. There is evidence reported that Mali and Songhay empires had reed built boats 113 x 13 feet long, capable of carrying 80 tons of weight, and would be used to sail across the Atlantic to South America. They also made journeys to and from China. Reconstruction of these vessels has been used to successfully demonstrate their ancient use for transatlantic voyages. Evidence of crop science in ancient times was discovered in Kenyan highlands and along the Nile banks including cattle domestication and barley cultivation which occurred 18000 years ago. African traditional medicines covers early uses of antiseptics, vaccination, anaesthetics, surgery. Examples include use of tree back which contains salicylic acid, a key ingredient of aspirin. Cure of diarrhea using kaolin was used in Mali and treatment of skin infections was developed by Nigerian doctors. A native cesarean operation in Kahura by Banyoro tribesmen of Uganda was reported in 1879 to have existed for long [13-14]. It was performed by a native surgeon using banana juice and extracts 
from plant roots. The native cesarean surgery was practiced well before the first ever successful medical Cesearean operation was done between 1815-21 in Cape Town, South Africa, while the first European cesearean operation was performed at Padua in 1876.

Table 1. Summary of some early scientific and engineering discoveries of Ancient Africa [10-14]

\begin{tabular}{|c|c|c|c|c|}
\hline $\begin{array}{l}\begin{array}{l}\text { Discipline \& } \\
\text { scholarship }\end{array} \\
\end{array}$ & Discovery & Location & Dating & Reported by \\
\hline $\begin{array}{l}\text { Materials } \\
\text { Engineering } \\
\text { \& Technology }\end{array}$ & Production of carbon steel & $\begin{array}{l}\text { Tanzania, Uganda } \\
\text { and Rwanda }\end{array}$ & $\begin{array}{l}1500-2000 \\
\text { years ago }\end{array}$ & $\begin{array}{l}\text { 1978: Prof. Peter } \\
\text { Schmidt, Professor of } \\
\text { Engineering \& Donald } \\
\text { Avery, Brown } \\
\text { University }\end{array}$ \\
\hline \multirow[t]{3}{*}{ Astronomy } & $\begin{array}{l}\text { A stone calendar based on } \\
\text { rising of certain stars and } \\
\text { constellations. }\end{array}$ & $\begin{array}{l}\text { Kenya, edge of } \\
\text { Lake Turkana }\end{array}$ & $300 \mathrm{BC}$ & $\begin{array}{l}\text { 1978: Dr B. M. Lynch } \\
\text { \& Prof. L. H. Robbins. } \\
\text { Michigan State } \\
\text { University, USA }\end{array}$ \\
\hline & $\begin{array}{l}\text { Astronomy in ancient Egypt } \\
\text { divided a year into } 12 \text { parts } \\
\text { and produced a yearly } \\
\text { calendar of } 3251 / 4 \text { days }\end{array}$ & Egypt & $3000 \mathrm{BC}$ & \\
\hline & $\begin{array}{l}\text { Dogon of Mali have had } \\
\text { precise knowledge of the } \\
\text { invisible Sirius B star for } \\
\text { hundreds of years }\end{array}$ & $\begin{array}{l}\text { Mali, about } 200 \\
\text { miles from Univ. } \\
\text { of Timbucktu }\end{array}$ & $\begin{array}{l}500-700 \\
\text { years ago }\end{array}$ & \\
\hline \multirow[t]{3}{*}{ Mathematics } & $\begin{array}{l}\text { The earliest recorded use of } \\
\text { algebra was among the } \\
\text { Egyptians }\end{array}$ & Egypt & & \\
\hline & $\begin{array}{l}\text { A numerical counting } \\
\text { system, named Ishongo, had } \\
\text { developed a lunar calendar } \\
\text { system }\end{array}$ & $\begin{array}{l}\text { Zaire (now } \\
\text { Democratic } \\
\text { Republic of } \\
\text { Congo) }\end{array}$ & $\begin{array}{l}20000 \\
\text { years ago }\end{array}$ & $\begin{array}{l}\text { 1960: Dr. de } \\
\text { Heinzelin. } \\
\text { Universities } \\
\text { of Ghent and Brussels, } \\
\text { Belgium }\end{array}$ \\
\hline & $\begin{array}{l}\text { Yoruba of Nigeria have a } \\
\text { complex number system of } \\
\text { counting of base } 20\end{array}$ & Nigeria & Native & \\
\hline \multirow[t]{2}{*}{$\begin{array}{l}\text { Architecture } \\
\& \text { mega- } \\
\text { engineering } \\
\text { projects }\end{array}$} & $\begin{array}{l}\text { The } 80 \text { Egyptian pyramids } \\
\text { presents an astounding } \\
\text { marvel of any engineering } \\
\text { project in human history. }\end{array}$ & Egypt & $2560 \mathrm{BC}$ & $\begin{array}{l}\text { Great pyramid of } \\
\text { Giza. }\end{array}$ \\
\hline & $\begin{array}{l}\text { Monomotapa - a large } \\
\text { stone complex found } 17 \\
\text { miles south of Zimbabwe's } \\
\text { city of Nyanda, an empire } \\
\text { of Shona people existed for } \\
300 \text { years }\end{array}$ & Great Zimbabwe & $\begin{array}{l}800 \text { years } \\
\text { old }\end{array}$ & \\
\hline $\begin{array}{l}\text { Navigation } \\
\text { and overseas }\end{array}$ & $\begin{array}{l}\text { Mali and Songhay empires } \\
\text { had reed built boats used to }\end{array}$ & West Africa & $13^{\text {th }}$ century & \\
\hline
\end{tabular}




\begin{tabular}{|c|c|c|c|c|}
\hline travel & $\begin{array}{l}\text { sail across the Atlantic to } \\
\text { South America, and to } \\
\text { China. }\end{array}$ & & & \\
\hline \multirow[t]{2}{*}{$\begin{array}{l}\text { Agricultural } \\
\text { science }\end{array}$} & Barley cultivation & $\begin{array}{l}\text { Pre-Egyptian age, } \\
\text { Nile banks }\end{array}$ & $\begin{array}{l}18000 \\
\text { years ago }\end{array}$ & $\begin{array}{l}\text { 1979: Prof. Fred } \\
\text { Wendorf, Southern } \\
\text { Methodist University, } \\
\text { USA }\end{array}$ \\
\hline & Cattle domestication & Kenya highlands & $\begin{array}{l}15000 \\
\text { years ago }\end{array}$ & $\begin{array}{l}\text { 1980: Dr. Charles } \\
\text { Nelson, University of } \\
\text { Massachusetts, USA. }\end{array}$ \\
\hline \multirow[t]{2}{*}{ Medicine } & $\begin{array}{l}\text { African traditional } \\
\text { medicines including early } \\
\text { uses of, anitsceptics, } \\
\text { vaccination, anaesthetics } \\
\text { and the surgery. amongst } \\
\text { many others }\end{array}$ & $\begin{array}{l}\text { Mali, Nigeria, } \\
\text { Liberia, Kenya }\end{array}$ & & \\
\hline & $\begin{array}{l}\text { Cesearean operation } \\
\text { natively conducted by } \\
\text { Banyoro of Uganda }\end{array}$ & Uganda & Native & $\begin{array}{l}\text { Dr. Charles Finch, } \\
\text { Morehouse School of } \\
\text { Medicine, USA; } \\
\text { Reported in 1879 by } \\
\text { Dr. Felkin [13] }\end{array}$ \\
\hline Scholarship & $\begin{array}{l}\text { University of Timbuktu in } \\
\text { Mali is considered to be one } \\
\text { of the worlds first } \\
\text { university. Founded in } 980 \\
\mathrm{AD} \text {, it had a student } \\
\text { population of about } 25000 \\
\text { students in the } 12^{\text {th }} \text { century. }\end{array}$ & Mali & 980AD & \\
\hline
\end{tabular}

\section{Domestication and Indigenization of Scientific Knowledge}

We learn from modern archeology and historical records that there have been great ancient civilisations with remarkable discoveries in Africa. One wonders how the empires would varnish altogether with their advanced ethnoscience, leaving no continuity for future humanity. It is notable that at different periods of history, there were pockets of ethnoscience and technology in isolated regions of the world. Van Sertima [10] attributes these losses of ancient science and technology to overconcentration of advances at the centre of these civilisations and the absence of interconnectedness with other civilisations. So once a particular civilization came to an end or was conquered, it disappeared with its scientific knowledge. Until the industrial revolution which only happened in the $18^{\text {th }}$ century, there was little or no technology transfer among the past civilizations.

It is evident from the modern advancements in SE\&T that two tenets of advancement of knowledge are crucial: (1) Exploitation of indigenous knowledge system (IKS), including ethno-science and technology. IKS is ethnic in origin, typically passed on from one generation to another over centuries. It is maintained through social and cultural practices that are unique to a particular people grouping or 
tribe. Often IKS is not receptive to external or imported knowledge incursions viewing these as pollutants [15]. (2) Adaptation of knowledge from international sources. Adaptation involves refinement of known technology through innovative improvements. The most important underlying condition for effective adaptation is the requirement for mastery of the known or imported SE\&T. Often this adaptation process would involve some form of research. Accordingly, for adaptation to be exploited as a platform for scientific advancement, expertise in the field must be developed which has the knowledge level equal or exceeding that of the original technology. For imported technologies, it is essential that the local expertise has to be of advanced level, capable of matching the international sources. This is where lies the most critical challenge in Africa, that is, to develop critical mass of research expertise.

One of the reasons that Africa's HEIs find difficulty in attempting to change SE\&T curricula is associated with the source of knowledge materials. At the present time, almost all knowledge in the scholarly books of SE\&T is taken from international sources overseas. SE\&T disciplines in Africa currently lack sufficient coordinating structures to infuse technology transfer through the academia and industry both locally and internationally [16]. Also, African countries need to reach advanced levels of research production necessary for endogenic creation of scientific knowledge to scientifically indigenize the core structure and direction of SE\&T curricula. So, it is necessary to develop researchers of the highest international expertise, which ensures prolific creation of new domestic scientific knowledge. Such local SE\&T knowledge developed through research and published in Journals and books, can soon diffuse into the teaching curricula. Local SE\&T knowledge needs to reach a level at which it matches and exceeds in certain respects, the established global knowledge available in the field.

\section{Conclusion}

Presently, African countries are mostly recipients of knowledge from international sources in the areas of Science, Engineering and technology curricula, with little or hardly any endogenic scientific inputs. This has led to trends in technology transfer as explained by diffusion theory. In the article, evidence of ancient scientific discoveries in Africa and projects of enormous engineering feats are enumerated from literature, involving various disciplines of material science, mathematical sciences, engineering, medicines, astronomy, education, amongst others. These roots are indicative and should indeed concientize us of the underlying potential for endogeneous science within the continent.

Acknowledgments. The study presented in this paper was funded by the National Research Foundation (NRF) of South Africa, IPRR Grant No. 96800. The author is grateful for the financial support given by NRF. 


\section{References}

1. Daud W.R.W and Zain S.M: Indigenisation of technology and the challenge of globalization: The case of Malaysia, MAAS Journal of Islamic Science, 1999, 15: 109-134

2. Parsons, T: Value-freedom and objectivity. In F.R. Dallmayr \& T.A. McCarthy (Eds.), Understanding and social inquiry (pp.56-65). Notre Dame: University of Notre Dame Press. 1977

3. WorldBank: Data on Sub-Saharan Africa, 2014. http://data.worldbank.org/region/SSA. Accessed 25 Mar 2016.

4. Ekolu S.O and Kazurikanyo J-B: Developing and focussing cement concrete technologies to accelerated, sustainable development in sub-saharan Africa, published in the Proceedings of the National Symposium on Concrete for a Sustainable Environment, Concrete Society of Southern Africa, held on 3-4th August 2010, Kempton Park, Johannesburg, Gauteng, p.173-179.

5. Malloy, J.: James Watson tells the inconvenient truth: Faces the consequences,Medical Hypotheses, 2008, 70, 1081-109.

6. Rushton, J. P., \& Jensen, A. R.: James Watson's most inconvenient truth: Race realism and the moralistic fallacy. Medical Hypotheses, 2008, 71, 629-640.

7. Lynn, R., \& Vanhanen, T: IQ and the wealth of nations, 2002. Westport, CT: Praeger.

8. Lynn, R., \& Vanhanen, T: IQ and globalinequality.Augusta, GA: Washington Summit Publishers, 2006

9. Wicherts Jelte M., Dolan Conor V., Carlson Jerry S., van der Maas Han L.J: Raven's test performance of sub-Saharan Africans: Average performance, psychometric properties, and the Flynn Effect, Learning and Individual Differences, 2010, 20, 135-151

10. van Sertima, I: The Lost Sciences of Africa: An Overview. Blacks in Science: Ancient and Modern 1983, 7 - 26.

11. Blatch S: Great achievements in science and technology in ancient Africa, February 2013, ASBMB Today, 32-33.

12. Wendorf Fred, Schild Romuald, El Hadidi Nabil, Close Angela E., Kobusiewicz Michael, Wieckowska Hanna, Issawi Bahay, Haas Herbert: Use of Barley in the Egyptian Late Paleolithic, Science 28 Sep1979: Vol. 205, Issue 4413, pp. 1341-1347, DOI: 10.1126/science.205.4413.1341

13. Felkin RW: Notes on labour in Central Africa. Edinburgh Medical Journal, 1884, 20: $922-$ 30.

14. de Costa Caroline: Banana wine and crossdressing, School of Medicine and, Dentistry, James Cook University, Vol 15 No 2 Winter 2013, 61.

http://www.ranzcog.edu.au/editions/doc_view/1373-60-banana-wine-and-crossdressing.html. Accessed 19 March 2016.

15. Yang R.: Internationalisation, indigenization and educational research in China, AARE Annual Conference, 2004, Mebourne, Australia

16. Ekolu S.O and Ballim Y. (2006), Technology transfer to minimize concrete construction failures, Proc. 1st Intl. Conf. on Advances in Engineering and Technology, Entebbe, Uganda, July 2006, 91-98. 